\author{
Ye.M. Tazhbayev ${ }^{1}$, M.Zh. Burkeyev ${ }^{1}$, L.Zh. Zhaparova ${ }^{1}$, \\ T.S. Zhumagalieva ${ }^{1}$, Zh.T. Arystanova ${ }^{1}$, D.A. Mukhanova ${ }^{2}$ \\ ${ }^{I}$ Ye.A. Buketov Karaganda State University, Kazakhstan; \\ ${ }^{2}$ LLP Biotron Group, Stepnogorsk, Kazakhstan \\ (E-mail:lyazzh@mail.ru)
}

\title{
Preparation and characterization of empty nanoparticles of poly-D,L-lactic acid and serum albumin
}

\begin{abstract}
The methods of preparation of polymeric nanoparticles and nanocapsules on the basis of such polymers as human serum albumin and poly-D,L-lactic acid are shown in this article. Human serum albumin and polyD,L-lactic acid are well-known polymers used in medicine for different purposes including delivery of some potent drugs in the forms of nanoparticles. Empty nanoparticles of human serum albumin and poly-D,L-lactic acid have been successfully synthesized using desolvation and nanoprecipitation methods correspondingly. Optimal conditions of synthesizing the nanoparticles of human serum albumin and poly-D,L-lactic acid have been worked out. Obtained nanoparticles of the polymers have satisfactory physicochemical characteristics: the particle sizes were in the interval of 100-300 nm with narrow particle size distribution which points on the formation of nanoparticles of similar size. The surface charge of the particles was defined as it is the parameter that determines the stability of the system. The meanings of zetapotential were around $-30 \mathrm{mV}$ for both systems which justifies the stability of particles within the time. So the results of this study have shown that synthesized nanoparticles of human serum albumin and poly-D,L-lactic acid have good characteristics and hence they can further be used for loading them with different drugs.
\end{abstract}

Keywords: polymers, polylactic acid, human serum albumin, nanoparticles, drug delivery, nanocapsules, nanoprecipitation, desolvation.

\section{Introduction}

Nanoparticulate systems such as nanoparticles and nanocapsules based on biocompatible polymers are becoming the subject of interest both for scientists and doctors. Such characteristics as small size, large surface area and stability within the time, make these systems unique and promising, especially in the controlled delivery of drugs. Nanocarriers were found to be accumulated in tumor tissues and in the inflamed tissues [1] and the particles of certain size are able to find the infected cells or tissues and act selectively without damaging healthy tissues. Also nano-size of such colloidal particles allows them to penetrate through narrow blood capillaries [2].

Nanosomal forms are constructed on the basis of commonly used biocompatible and biodegradable polymers. Human serum albumin (HSA) and poly-D,L-lactic acid (PLA) (Fig. 1) are well-known polymers which have found wide application in medicine as an auxiliary materials as well as polymeric carriers for different drug preparations. In this regard, the aim of this study was to synthesize empty polymeric nanoparticles of HSA and PLA with satisfactory physicochemical characteristics for loading them with drugs.<smiles>[R]C(N)[CH]C(=O)NC([R1])CC(=O)O</smiles>

(1)

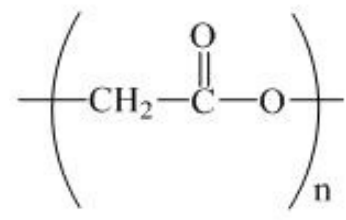

(2)

Figure 1. Structural formula of human serum albumin (1) and poly-D,L-lactic acid (2)

\section{Method}

\section{Preparation of empty nanoparticles of poly(D,L-lactic acid)}

Nanoparticles of PLA were obtained using the method of nanoprecipitation. Briefly, $0.2 \mathrm{ml}$ of water was added to $0.5 \mathrm{ml}$ of acetone. Then PLA was dissolved in $1 \mathrm{ml}$ of acetone and mixed with the solution prepared before. The polymer solution was added with a syringe to $5 \mathrm{ml}$ of the external phase (water) with 
slight stirring. The residual organic solvent was evaporated for 40 minutes under reduced pressure on a vacuum rotary evaporator «Vacuum controller V-855» (Buchi, Switzerland) and the dispersion of the nanoparticles was diluted with water to $20 \mathrm{ml}$ and filtered (paper filter) to remove any large formations.

\section{Preparation of empty HSA nanoparticles}

Empty HSA nanoparticles were prepared using a desolvation method [3]. The pH of HSA solution of albumin ( $2 \%$ ) was adjusted to 8.3 with buffer solution. Then under constant stirring $(600 \mathrm{rpm})$ at room temperature $8 \mathrm{ml}$ of ethanol $(96 \%)$ was added to the mixture $(1 \mathrm{ml} / \mathrm{min})$ using a tubing pump. After the desolvation process the particles were stabilized by the addition of an aqueous $8 \%$ glutaraldehyde solution (1.175 $\mu \mathrm{l}$ per ml HSA). After that the suspension was stirred for $24 \mathrm{~h}$. The nanoparticles were separated from low molecular components by repeated centrifugation with the Centrifuge MiniSpin Plus 14500 (Eppendorf, Hamburg, Germany) at $14500 \mathrm{rpm}$ and washing them with water.

\section{Measurement of particle size, zeta potential $(\zeta)$ and particle size distribution}

Average particle diameter and the particle size distribution of PLA and HSA nanoparticles were determined at $25^{\circ} \mathrm{C}$ by dynamic light scattering (DLS) on a Malvern Zetasizer Nano ZS instrument at a scattering angle of $173^{\circ}$. The zeta potential was also measured on this device. Nanoparticles were previously diluted with a phosphate-buffer ( $\mathrm{pH}$ 7.4) and the zeta potential was determined by Laser Doppler micro electrophoresis.

\section{Results and Discussion}

There are a number of methods for synthesizing nanoparticles: emulsion polymerization, emulsification-diffusion, interfacial deposition, desolvation, nanoprecipitation, solvent evaporation/extraction and solvent displacement methods there [1,2,4-7]. The method of preparation of polymeric nanoparticles and nanocapsules can be chosen depending on the goals, technological advantages, the properties of the substances entrapped and the polymeric materials to be used [1,2, 4-7].

Nanoparticles of HSA can be synthesized by protein denaturation in an water-in-oil emulsion and applying desolvation (coacervation) methods as shown in $[1,3]$. When obtaining albumin nanoparticles by desolvation, HSA is dissolved in water and then desolvated with ethanol and stabilized by addition of a cross-linker which is glutaraldehyde. Particle size of the synthesized nanoparticles usually varies between 80-300 $\mathrm{nm}$. Therefore empty HSA nanoparticles have been obtained using desolvation method at a $\mathrm{pH}$ meaning of 8.3. In this case the particles of optimal size and relatively big surface area are formed. It allows high degree of adsorption of the drug on the surface of particles. In this method the addition of amphiphilic solvent, i.e. ethanol drop-wise to the concentrated solution of albumin is relevant, as the volume of ethanol is 4-5 fold higher than water and addition of the whole amount of ethanol may lead to the formation of insoluble aggregates of albumin or albumin nanoparticles of non-spherical structure. Slow addition of ethanol is also necessary to stabilize the system and homogeneous formation of albumin nanoparticles, hence colloidal particles of spherical shape with monomodal distribution can be obtained. Afterwards the HSA nanoparticles are crosslinked with the help of small amount of glutaraldehyde. Hardened nanoparticles of albumin do not change their shape and physical state even after multifold centrifugation and dissolving.

Physicochemical characteristics of synthesized empty HSA nanoparticles were determined using photon correlation spectroscopy, of which the results are given in Figure 2.

From Figure 2 it is seen that obtained nanoparticles have very good characteristics: optimal size $(d=151.2 \mathrm{~nm})$ and narrow particle size distribution $(\mathrm{PDI}=0.094)$. The portion of particles of nanometer size is $100 \%$, which meets the requirements of polymeric carriers.

Another interesting polymer from the point of view of carriers for different active agents is poly-D,Llacitc acid. Polymeric nanoparticles based on PLA are gaining interest among the scientists as this polymer possesses such properties as biocompatibility and biodegradability.

One of the methods of synthesizing nanoparticles of PLA is nanoprecipitation. A number of experiments on the selection of optimal conditions of synthesizing PLA nanoparticles have been carried using THF, acetone and the mixture of acetone with ethanol as solvents. The choice of these solvents is due to the solubility of PLA in these solvents and by their ability to mix with water. The study on selection of optimal solvent has shown that acetone was the best one for the formation of nanoparticles. In this case the nanoparticles with satisfactory characteristics were obtained (Fig. 3). 


\begin{tabular}{|c|c|c|c|c|c|}
\hline & & & Size (d.nm): & $\%$ Intensity & Width (d.nm): \\
\hline Z-Average (d.nm): & 151,2 & Peak 1: & 154,0 & 100,0 & 29,18 \\
\hline Pdl: & 0,094 & Peak 2: & 0,000 & 0,0 & 0,000 \\
\hline Intercept: & 0,761 & Peak 3: & 0,000 & 0,0 & 0,000 \\
\hline
\end{tabular}

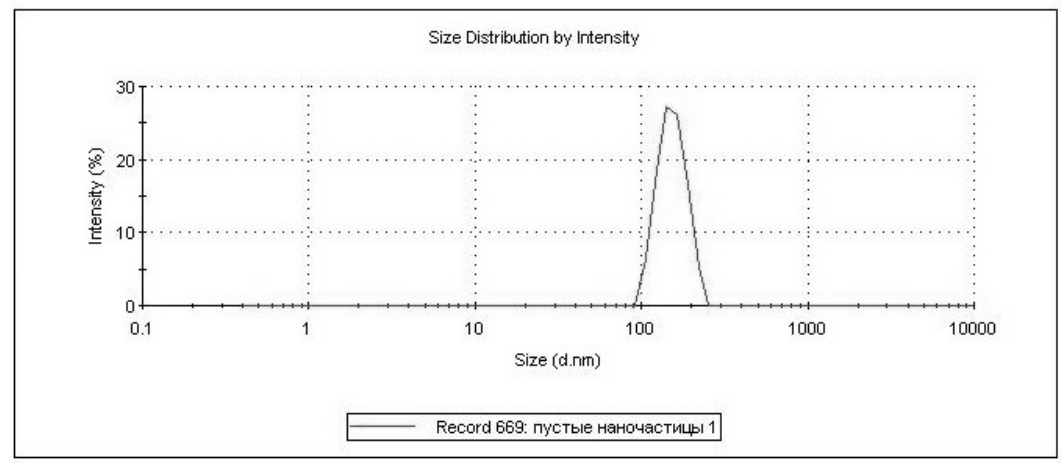

Figure 2. Particle size distribution of empty HSA nanoparticles

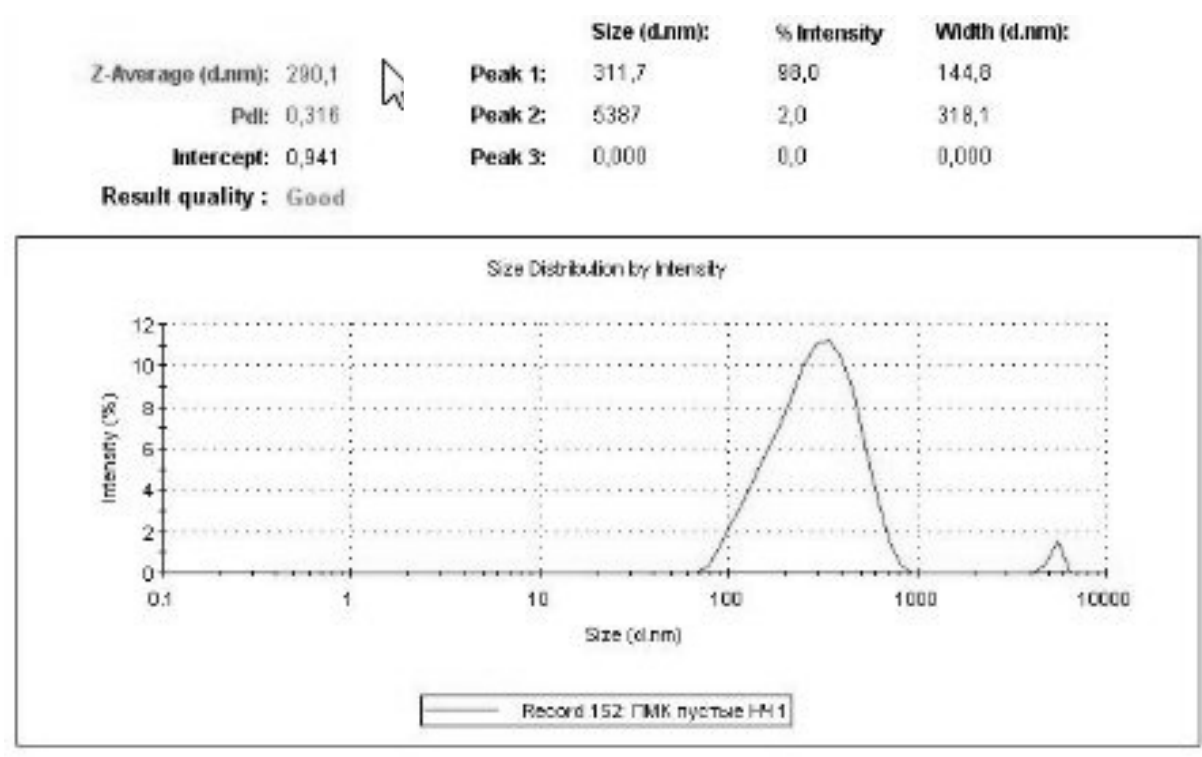

Figure 3. Particle size distribution of empty PLA nanoparticles

It is clear from Figure 3, that the system mainly consists of the particles with nanometer size and only $2 \%$ of the system is microparticles.

Physicochemical characteristics of empty PLA and HSA nanoparticles are summarized in Table.

$\mathrm{T} \mathrm{a} \mathrm{b} \mathrm{le}$

Physicochemical characteristics of empty PLA and HSA nanoparticles

\begin{tabular}{|l|c|c|}
\hline \multicolumn{1}{|c|}{ Parameter } & Empty PLA nanoparticles & Empty HSA nanoparticles \\
\hline Average particle size, $d, \mathrm{~nm}$ & 290.1 & 151.2 \\
\hline PDI & 0.316 & 0.094 \\
\hline Zetapotential, $\mathrm{mV}$ & -35.0 & -31.0 \\
\hline Molecular mass & 1520.0 & - \\
\hline Yield of nanoparticles, $\%$ & 76.6 & 98.2 \\
\hline
\end{tabular}

Together with particle size and size distribution such parameter as the surface charge of the particles needs to be evaluated. In addition, better targeting can be accomplished by obtaining monodisperse systems and/or by attaching antibodies or ligands on the surface of nanoparticles [7,8]. When synthesizing polymeric nanoparticles one of the important parameters is the surface charge as together with the meaning of size and 
particle size distribution it defines the biodistribution of nanoparticles after administering them into the body. Surface charge of the particles is characterized by zeta potential which is an indicator of the stability of the colloidal system. In this case the absence of excess counter ions is important because it may lead to aggregation; the latter is not acceptable when using polymeric nanoparticles for the drug delivery purposes. According to the results of measuring zetapotential in both cases the systems are stable (Table) as the meanings of surface charge were not close to 0 .

\title{
Conclusions
}

So at this stage of the research empty nanoparticles of PLA and HSA with high yield have been successfully synthesized. Physicochemical characteristics of obtained particles meet the requirements of the polymeric carriers of drug preparations; therefore they are aimed to be used for loading with such antitumor drugs as tamoxifen and cyclophosphamide.

\section{References}

1 Kreuter, J. (1994). Nanoparticles: Colloidal Drug Delivery Systems. New-York: Marcel Dekker, USA.

2 Kreuter, J. (2007). Nanoparticles — a historical Perspectives. Int. J. Pharm. 331, 1-10.

3 Dreis, S., Rothweiler, F., Michaelis, M., Cinatl, Jr., Kreuter, J., \& Langer, K. (2007). Preparation, characterization and maintenance of drug efficacy of doxorubicin-loaded human serum albumin nanoparticles. Int. J. Pharm., 341, $207-214$.

4 Prasad, R.J., \& Geckeler, K.E. (2011). Polymer Nanoparticles: Preparation techniques and size control parameters. Progr. Polymer Sci., 36, 887-913.

5 Fessi, H., Puisieux, F., \& Devissaguet, J.P., et al. (1989). Nanocapsule formation by interfacial polymer deposition following solvent displacement. Int. J. Pharm., 55, $1-4$.

6 Alleman, E., Gurny, R., \& Doelker, E. (1993). Drug-loaded nanoparticles — preparation methods and drug targeting issues. Review. Eur. J. Pharm. Biopharm. 39(5), 173-191.

7 Moghimi, S.M., Hunter, A.C., \& Murray, J.C. (2005). Nanomedicine: current status and future prospects. FASEB J., 19, 311322.

\author{
Е.М. Тажбаев, М.Ж. Буркеев, Л.Ж. Жапарова, \\ Т.С. Жұмағалиева, Ж.Т. Арыстанова, Д.А. Мұханова
}

\section{Поли-D,L-cүт қышқылы мен сарысу альбуминнің бос нанобөлшектерін синтездеу және сипаттау}

\begin{abstract}
Мақалада сарысу альбумин мен поли-D,L-cүт қышқылының полимерлі нанобөлшектері мен нанокапсулаларын алу әдістері көрсетілген. Адамның сарысу альбумині және поли-D,L-сүт қышқылы медицинада әртүрлі мақсатта, соның ішінде кейбір әсері күшті дәрілік заттарды нанобөлшектер түріндегі жеткізуші ретінде қолданылатын белгілі полимерлер болып табылады. Альбумин мен полиD,L-cүт қышқылының нанобөлшектерін синтездеудің ықшамды жағдайлары табылды. Сарысу альбуминнің және поли-D,L-cүт қышқылының бос нанобөлшектері сәйкесінше десольваттау және нанотұндыру әдістерімен синтезделді. Алынған полимерлі нанобөлшектер қанағаттанарлық физикахимиялық сипаттамаларға ие: бөлшектердің өлшемі 100-300 нм аралығында, ал бөлшектердің өлшем бойынша таралуы тар болды, бұл өлшемі жағынан біртекті бөлшектердің түзілгенін көрсетеді. Бөлшектердің беттік заряды анықталды, себебі бұл өлшем жүйенің тұрақтылығына жауап береді. Дзетапотенциал өлшемдері екі жүйе үшін де шамамен -30мВ-қа тең болды, бұл бөлшектердің уақыт бойынша тұрақтылығын білдіреді. Осылайша, бұл зерттеулердің нәтижесі синтезделген сарысу альбумин және поли-D,L-cүт қышқылының нанобөлшектерінің жақсы сипаттамаларға ие екендігін және оларды әрі қарай әртүрлі дәрілік препараттармен иммобилизациялауға болатындығын көрсетті.
\end{abstract}

Кілт сөздер: полимерлер, полисүт қышқылы, адамның сарысу альбумині, нанобөлшектер, дәрілік заттарды тасымалдау, нанотұндыру, десольвация. 


\section{Е.М. Тажбаев, М.Ж. Буркеев, Л.Ж. Жапарова, Т.С. Жумагалиева, Ж.Т. Арыстанова, Д.А. Муханова \\ Получение и характеристика пустых наночастиц поли-D,L-молочной кислоты и сывороточного альбумина}

В статье показаны способы синтеза полимерных наночастиц и нанокапсул на основе сывороточного альбумина человека и поли-D,L-молочной кислоты. Сывороточный альбумин человека и поли-D,Lмолочная кислота являются хорошо известными полимерами, используемыми в медицине для различных целей, в том числе для доставки некоторых сильнодействующих лекарств в форме наночастиц. Найдены оптимальные условия синтеза полимерных наночастиц сывороточного альбумина и поли$\mathrm{D}, \mathrm{L}-$ молочной кислоты. Пустые наночастицы человеческого сывороточного альбумина и поли-D,Lмолочной кислоты синтезированы методами десольвации и наноосаждения соответственно. Полученные полимерные наночастицы имели удовлетворительные физико-химические характеристики: размеры частиц варьировали в интервале 100-300 нм с узким распределением частиц по размерам, что указывает на образование частиц одного размера. Определен поверхностный заряд частиц, так как эта величина отвечает за стабильность системы. Значения дзетапотенциалов равнялись около $-30 \mathrm{мB}$ для обеих систем, что свидетельствует о стабильности частиц во времени. Таким образом, результаты данного исследования показали, что синтезированные наночастицы сывороточного альбумина человека и поли-D,L-молочной кислоты имеют хорошие характеристики и, следовательно, могут быть в дальнейшем использованы для иммобилизации их различными лекарственными препаратами.

Ключевые слова: полимеры, полимолочная кислота, сывороточный альбумин человека, наночастицы, доставка лекарств, нанокапсулы, наноосаждение, десольвация. 